\title{
Sustainable Alkylation of Unactivated Esters and Amides with Alco- hols Enabled by Manganese Catalysis
}

\author{
Yoon Kyung Jang, Tobias Krückel, Magnus Rueping* and Osama El-Sepelgy* \\ Institute of Organic Chemistry, RWTH Aachen University, Landoltweg 1, 52074 Aachen, Germany, \\ KAUST Catalysis Center (KCC) King Abdullah University of Science and Technology (KAUST), Thuwal 23955-6900 (Saudi Arabia) \\ Supporting Information Placeholder
}

\begin{abstract}
The first example of manganese catalyzed $C$-alkylation of the carboxylic acid derivatives is reported. The benchstable homogenous manganese complex enables the transformation of the renewable alcohol and carboxylic acid derivative feedstock to higher value esters and amides. The reaction operates via hydrogen autotransfer and, ideally produces water as the only side product. Importantly, aliphatic, benzylic, and heterocyclic containing alcohols could be used as alkylating reagents, eliminating the need of the mutagenic alkyl halides.
\end{abstract}

The catalytic functionalization of the $\mathrm{C}-\mathrm{H}$ bonds is a central challenge in modern chemistry. ${ }^{1}$ Carboxylic acids and its derivatives are pervasive in nature. Accordingly, an elegant approach to utilize the readily available esters and amides is to convert them to more valuable intermediates upon $\alpha$-alkylation reaction. Conventional non-catalytic methods for the $\alpha$-alkylation of the carbonyl compounds involve the generation of the corresponding enolate nucleophile using superbase (such as organolithium or alkali metal amides) at very low temperature. In addition to the need for toxic alkyl halide electrophile, such methods suffer from the low-atom economy and the generation of copious amounts of waste. ${ }^{2}$

Recently, the alkylation of the carbonyl compounds with primary alcohols using hydrogen autotransfer strategy has emerged as an environmentally friendly alternative for the conventional alkylation methods. ${ }^{3}$ The key features of this hydrogen neutral process are the use of the alcohols as a green electrophile and the only stoichiometric by-product is water. Alcohols are renewably available from the lignocellulosic biomass and a variety of industrial processes. ${ }^{4}$ In fact, progress has been made in the $\alpha$-alkylation of ketones and $\beta$-alkylation of alcohols. ${ }^{5,6}$ In contrast, the $\alpha-\mathrm{C}-\mathrm{H}$ bonds of the esters and amides exhibit comparably low Brønsted acidity owing to the resonance stabilization effect of the adjacent $\mathrm{NR}_{2}$ group. Furthermore, esters typically undergo side reactions such as selfcondensation and transesterification. Among the carboxylic acid derivatives, the functionalization of dimethylacetamide (DMA) and $t$-butyl acetate is of particular interest, because these compounds can be obtained in one step from acetic acid and are frequently used as solvents in synthetic chemistry. Only a few reports are known for the $\alpha$-alkytion of esters and amides using iridium $^{7}$ and ruthenium ${ }^{8}$ catalysis. Very recently, Kempe and coworkers have reported an elegant cobalt catalyzed alkylation of esters and amides. However, the extensive need of the glovebox may complicate the large scale application. $^{9}$
For sustainability reasons, the current key challenge is the development of efficient catalytic systems that rely on the use of widely abundant, inexpensive metals. ${ }^{10}$ Manganese, the third most abundant transition metal, was recently recognized by several groups including ours as a potential alternative for the toxic noble metal in the hydrogenation of polar ${ }^{11}$ and nonpolar bonds, ${ }^{12}$ acceptorless dehydrogenation transformations, ${ }^{13}$ $C$ - and $N$ - alkylation with primary alcohols. ${ }^{5 e-5 i, 14}$ Despite the recent advances, ${ }^{15}$ the alkylation of the esters and amides via hydrogen autotransfer strategy remains unsolved challenge. Herein we report the first example of manganese catalyzed $\alpha$ alkylation of unactivated esters and amides with alcohols alcohols (Scheme 1). Our catalytic system features a bench stable catalyst stabilized by an air stable PNN ligand.

Scheme 1: Unprecedented Manganese Catalyzed C-H Functionalization of Esters and Amides

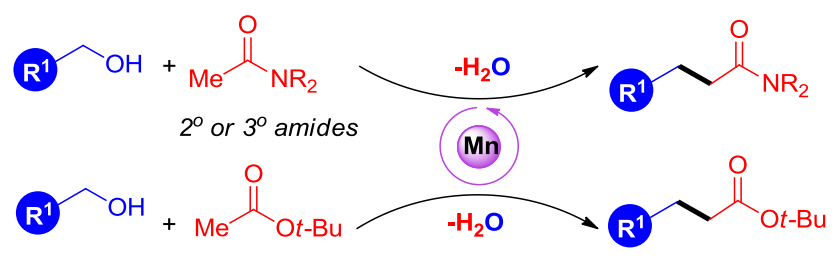

The $C$-alkylation of DMA with benzyl alcohol (1a) was selected as a model reaction for the optimization of the reaction conditions (Table 1). Initially, we tested the catalytic activity of different manganese complexes (Mn-1 to $\mathbf{M n - 3})^{16}$ in 1,4dioxane using $t$-BuOK as a base. While the PNP-Mn complexes Mn-1 and Mn-2 gave unsatisfied results, $\mathbf{M n - 3}$ bearing a PNN ligand afforded the desired alkylated amide $\mathbf{3 a}$ in $91 \%$ yield (Table 1, entries 1-3). Thus, Mn-3 was selected for the further optimization of the common reaction parameters such as base and solvent. It was found that efficiency of the reaction was dropped upon the use of $t$-BuOLi and $t$-BuONa (Table 1, entry 4,5). Additionally, the relatively weak bases such as 
$\mathrm{Cs}_{2} \mathrm{CO}_{3}$ and $\mathrm{Na}_{2} \mathrm{CO}_{3}$ were inert in this transformation (Table 1, entries 6,7). Similarly, $\mathrm{NaOH}$ and $\mathrm{KOH}$ proved not to suitable for this reaction (Table 1, entries 8,9). Next we examined different solvents. The use of another polar aprotic solvents such as 2-Me-THF and diglyme result in the formation of the desired product in $57 \%$ and $9 \%$ yields respectively (Table 1, entries 10,11). The application of the non-polar toluene led to lower yield compare to the 1,4-dioxane (Table 1, entry 12). In summary the reaction works best using $3 \mathrm{~mol} \%$ of $\mathbf{M n - 3}$ and 1.2 equiv. of $t$-BuOK in 1,4 -dioxane at $130{ }^{\circ} \mathrm{C}$.

Table 1. Optimization of the Reaction Conditions ${ }^{a}$

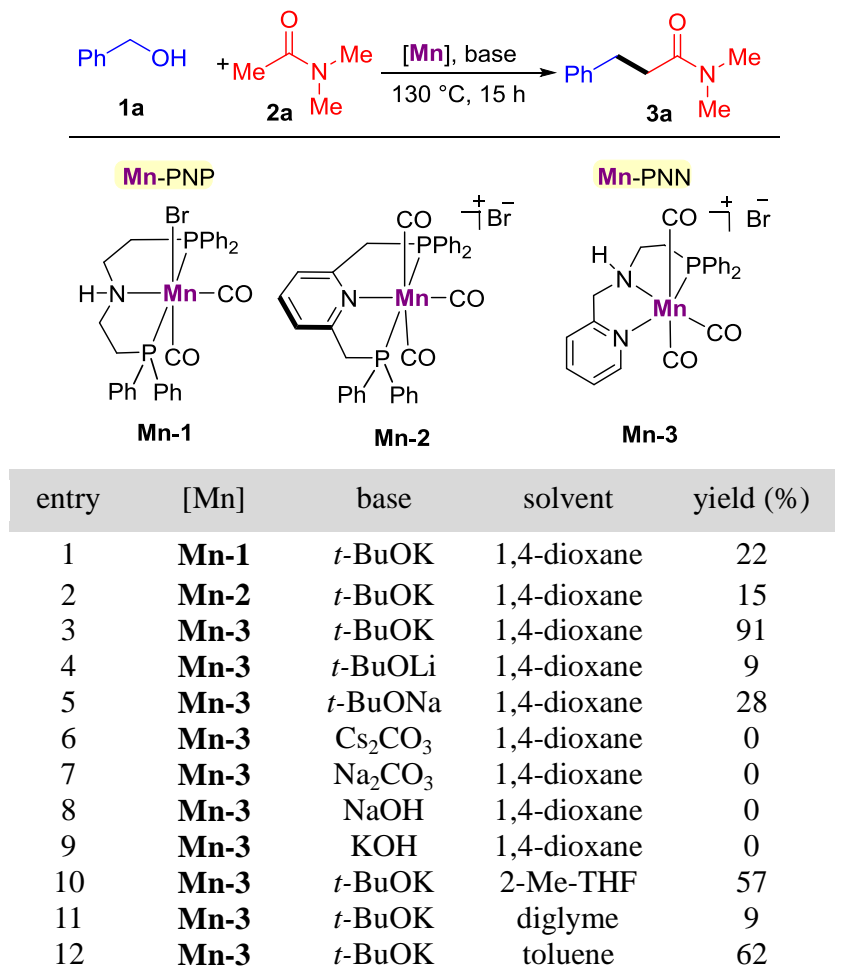

${ }^{a}$ Reaction conditions: 1a $(0.5 \mathrm{mmol})$, 2a $(1.5 \mathrm{mmol}),[\mathbf{M n}]$ (0.015 mmol), base (0.6 mmole), solvent $(1 \mathrm{~mL}), 130{ }^{\circ} \mathrm{C}, 15 \mathrm{~h}$. Yields determined by GC analysis using $m$-xylene as an internal standard.

With the optimized conditions in hand, we explored the scope of the $\alpha$-alkylation of amides with alcohols (Table 2). First, the scope of the alkylation of $\mathrm{N}, \mathrm{N}$-dimethylacetamide with alcohols was investigated. Benzylic alcohols bearing electrondonating or electron substituents in the ortho, meta and parapositions delivered the corresponding alkylated amide $\mathbf{3 a}-\mathbf{3 d}$ in good to excellent yield (Table 2, entries 1-4). Similarly, 1naphthalenemethanol performed well in this transformation and gave the $3 \mathbf{e}$ in $72 \%$ yield (Table 2 , entry 5). Importantly, alcohols bearing different hetrocyclic moieties; furane, thiophene and pyridine, were tolerated and the high-value added amides $\mathbf{3 f}-\mathbf{3 h}$ were obtained in good yield (Table 2, entries 6-8). Furthermore, long chain and $\alpha$-branched aliphatic alcohols could be used in this new method to produce the $C$ alkylated amide derivatives $\mathbf{3 i}-\mathbf{3 k}$ in good yields (Table 2, entries 9-11). Afterwards, we investigated different types of amides. Pleasantly, when $N, N$-diethylacetamide and 4acetylmorpholine $\mathbf{2 b}$ and $\mathbf{2 c}$ were subjected to the reaction, the alkylation products were obtained in moderate yields (Table 2, entries 12-13). Importantly, this catalytic system was not limited to the alkylation of the tertiary amide. Thus, the selective alkylation of $N$-methyl acetamide resulted in the formation of the desired $C$-alkylated products $\mathbf{3 n}$ and $\mathbf{3 o}$ in $53 \%$ and $86 \%$ yields (Table 2, entries 14-15). It is worth noting that the conventional alkylation of secondary amides using alkyl halides often leads to the $N$-alkylation products. ${ }^{2 c}$ Afterwards, we examined our catalytic system for the alkylation of the 2oxindole derivative $\mathbf{2 p}$. Indeed, the alkylation reaction proceeds well followed $\mathrm{C}-\mathrm{H}$ hydroxylation to afford the $\mathrm{C} 3-$ hydroxy functionalized 2-oxoindole $\mathbf{3 p}$ in $87 \%$ yield (Table 1 , entry 16).

Table 2. Manganese Catalyzed Alkylation of Amides ${ }^{a}$

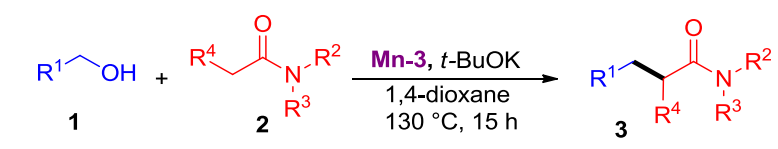

$$
\text { (5) }
$$
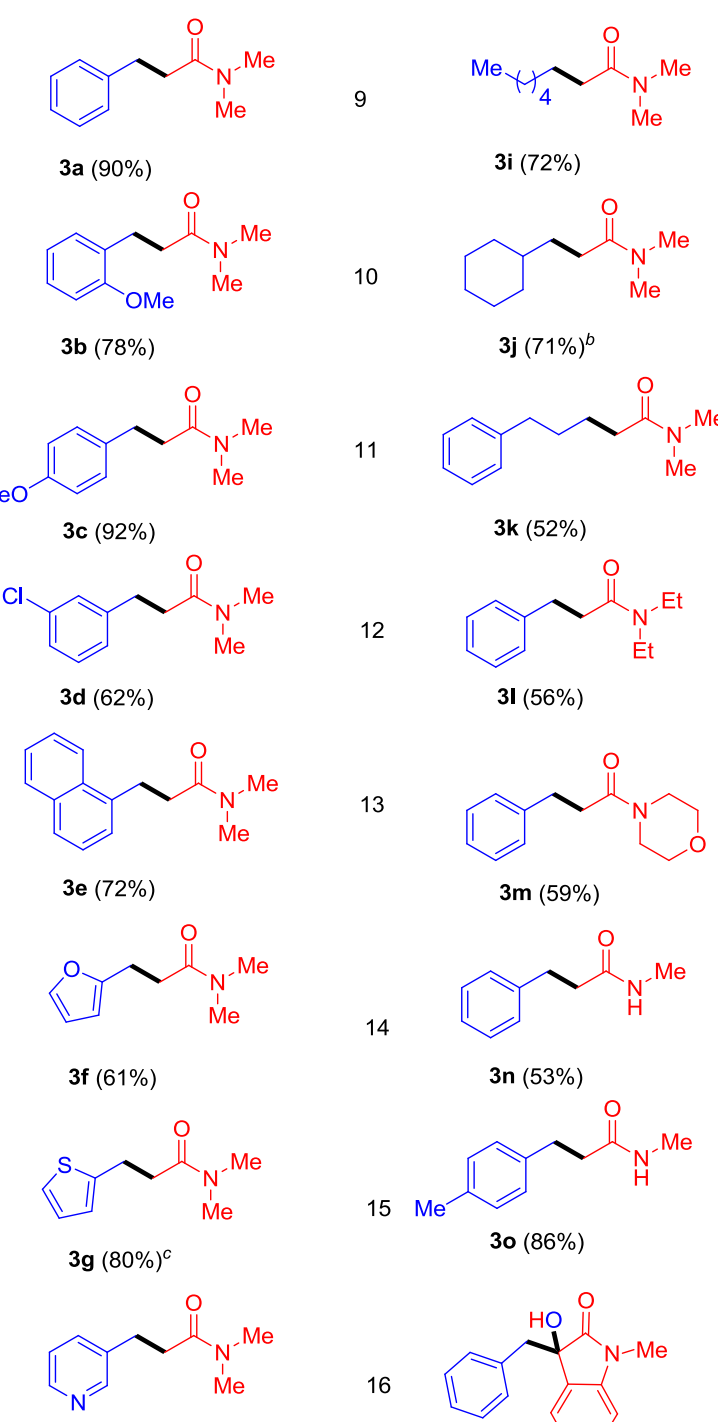
${ }^{a}$ Reaction conditions: 1 (0.5 mmol), 2 (1.5 mmol), Mn-3 (0.015 mmol), $t$-BuOK (0.6 mmol), 1,4-dioxane $(1.0 \mathrm{~mL}), 15 \mathrm{~h}, 130^{\circ} \mathrm{C}$. Isolated yields are shown. ${ }^{b} t$-BuOK $(1.0 \mathrm{mmol}) .^{c} 1 \mathrm{mmol} \mathrm{scale}$.

Encourage by these results, we decided to further expand the scope to the alkylation of esters. Thus, the reaction condition for the $t$-butyl acetate alkylation with benzyl alcohol was investigated. In summary, the best conditions involve the use Mn-3 and 2 equiv. of $t$-BuOK in toluene at $100{ }^{\circ} \mathrm{C}$ for $4 \mathrm{~h}$. We then focused on the substrate scope (Table 3 ). The application of the benzyl alcohol as a coupling partner gave the desired product 5a in $58 \%$ yield (Table 3, entry 1). Benzylic alcohols containing para-methyl, para-methoxy and meta-chloro were compatible to the reaction conditions and the $C$-alkylated esters $\mathbf{5 b}-\mathbf{5 d}$ were obtained in moderate yields (Table 3, entries 2-4). The application of 1-naphthalenemethanol led also to the desired product $\mathbf{5 e}$ in moderate yield (Table 3, entry 5). Noteworthy, thiophene containing substrate and product such as $\mathbf{5 f}$ are tolerated in this alkylation reaction (Table 3, entry 6).

Table 3. Manganese Catalyzed Alkylation of Esters ${ }^{a}$
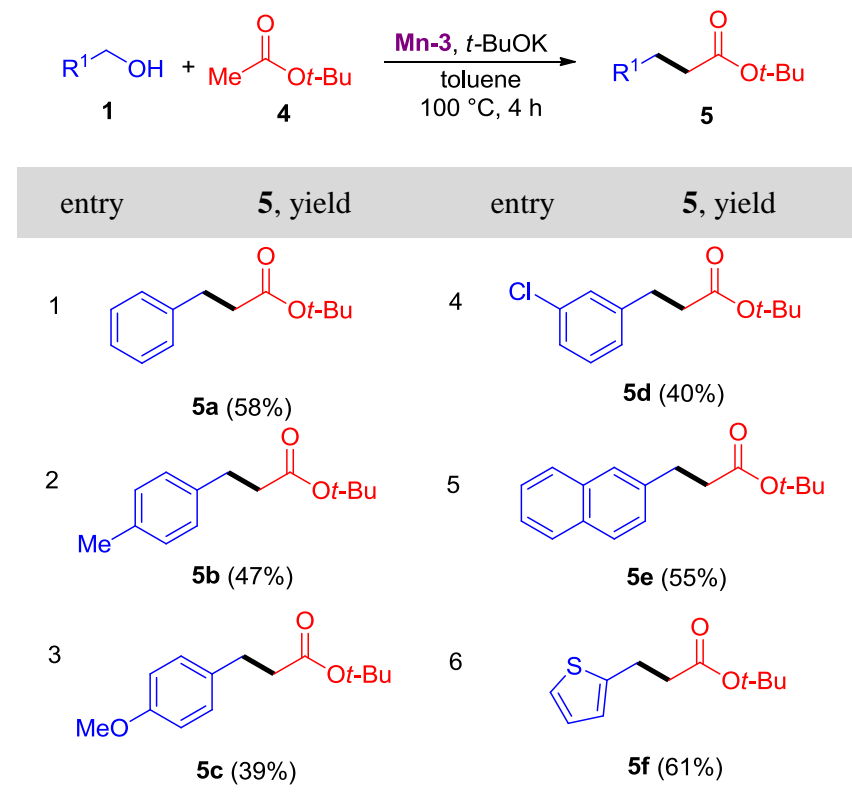

${ }^{a}$ Reaction conditions: 1 (0.5 mmol), 4 (2 mmol), Mn-3 (0.025 mmol $)$ and $t$-BuOK $(1 \mathrm{mmol})$, toluene $(1 \mathrm{~mL}), 100{ }^{\circ} \mathrm{C}, 4 \mathrm{~h}$. Isolated yields are shown.

In order to gain more insight in the reaction mechanism we carried out a deuterium labeled experiment (Scheme 2). In more details, $\left[\mathrm{D}_{2}\right] \mathbf{1 a}$ was used an alkylating reagent for the DMA. However, the catalyst loading was increased to $5 \mathrm{~mol}$ $\%$, only $49 \%$ yield was observed, which indicate a very strong kinetic isotope effect. Furthermore, the alkylated amide 3a' was obtained with $>90 \%$ deuterium incorporation at $\mathrm{C} 3$ and very low deuteration at $\mathrm{C} 2$. The deuterium experiment indicates that the hydrogen autoransfer reaction takes place via monohydride mechanism with the involvement of both of the metal and the non-innocent in dehydrogenation and the hydrogenation steps. ${ }^{17-19}$
Based on our experimental observations, the proposed reaction mechanism is presented in Scheme 3. Initially, proton transfer from the alcohol to the $16 \mathrm{e}$ species $\mathbf{A}$ takes place to generate the manganese alkoxide intermediate B. Subsequently, $\beta$ hydride elimination leads to the formation of an aldehyde and the hydrogenated catalyst $\mathbf{C}$, storing the abstracted hydrogen on the metal ligand catalyst. The base catalyzed condensation between the in situ generated aldehyde and carboxylic acid derivative result in the formation of an unsaturated amide. The shuttled hydrogen on the hydrogenated catalyst $\mathbf{C}$ is then transferred to the $\mathrm{C}=\mathrm{C}$ bond in two discrete steps. First, the hydride transfer takes place to produce the intermediate D. Second, the desired product is released upon proton transfer and regenerating the manganese specie $\mathbf{A}$. The proton transfer may also occur by transferring a proton directly from an alcohol, producing the desired product and the intermediate $\mathbf{B}$ without the re-generation of the $16 \mathrm{e}$ species $\mathbf{A} .^{20}$

Scheme 2: Deuterium Labeled Experiment

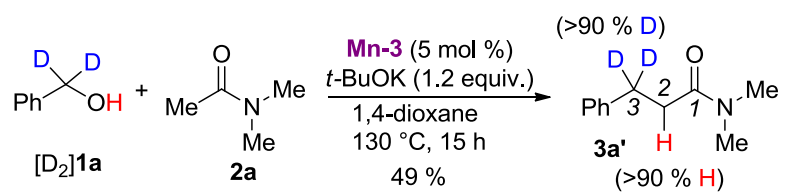

Scheme 3: Proposed Reaction Mechanism

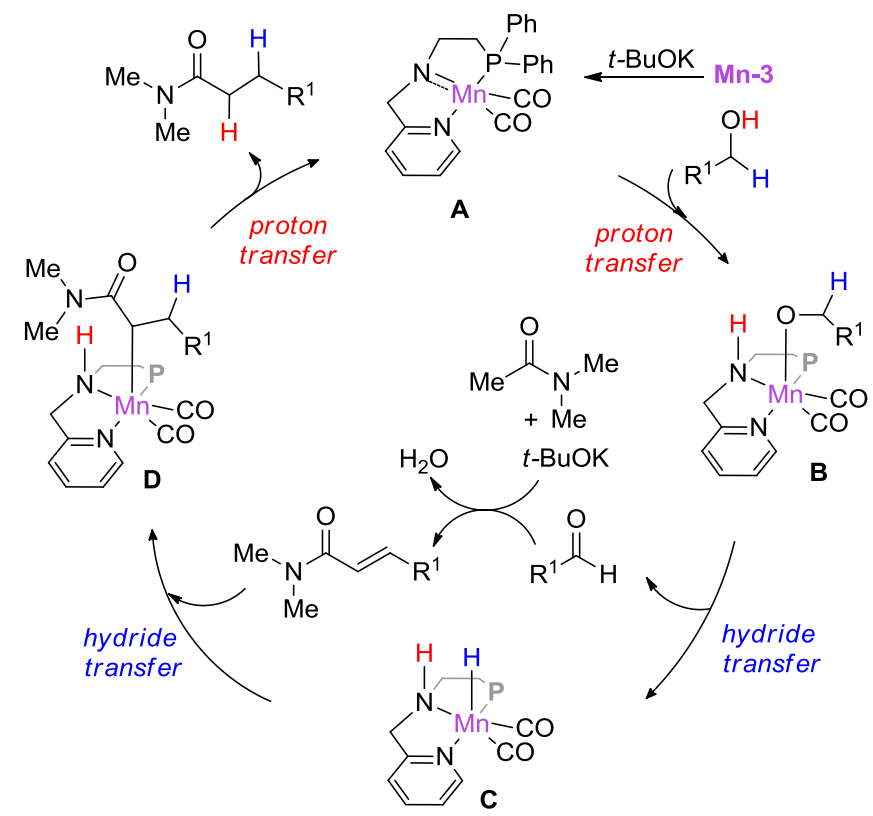

In conclusion, we have reported the first example of manganese catalyzed environmentally benign $C$-alkylation of unactivated esters and amides with the unactivated alcohols. ${ }^{21}$ The reaction tolerates a wide range of function groups and heterocyclic moieties, providing highly useful upgraded amides and esters in excellent efficiency. The presented sustainable alkylation reaction liberates water as the only side product.

\section{ASSOCIATED CONTENT}

\section{Supporting Information}

The Supporting Information is available free of charge on the ACS Publications website at DOI: 10.1021/acs.orglett.xxxxx 
Experimental details and characterization data (PDF)

\section{AUTHOR INFORMATION}

\section{Corresponding Author}

*Email: magnus.rueping@ rwth-aachen.de

*Email: osama.elsepelgy@rwth-aachen.de

\section{ORCID}

Magnus Rueping: 0000-0003-4580-5227

Osama El-Sepelgy: 0000-0003-3131-4988

\section{Note}

The authors declare no competing financial interest.

\section{REFERENCES}

(1) (a) Liu, W.; Ackermann, L. ACS Catal. 2016, 6, 3743 3752. (b) Wang, C. Synlett 2013, 24, 1606- 1613. For a recent example: Liu , W.; Cera, G.; Oliveira, J. C. A.; Shen, Z.; Ackermann, L., Chem. Eur. J. 2017, 23, $11524-11528$

(2) (a) Carey, F. A.; Sundberg R. K. Advanced Organic Chemistry, 5th ed., Part B, Springer, Heidelberg, 2007, pp. 1-31. (b) J. Hoyle in The Chemistry of Acid Derivatives, Vol. 2 (Ed.: Patai, S.), Wiley, Chichester, UK, 1992, pp. 615 - 702. (c) Challis, B. C.; Challis, J. The Chemistry of Amides; (Ed. Zabicky, J.), John Wiley \& Sons: London, 1970, pp 731-857.

(3) Selected Recent Reviews: (a) Corma, A.; Navas, J.; Sabater, M. J. Chem. Rev. 2018, 118, 1410. (b) Crabtree, R. H. Chem. Rev. 2017, 117, 9228-9246. (c) Chelucci, G. Coord. Chem. Rev. 2017, 331, 1-36. (d) Huang, F.; Liu, Z.; Yu, Z. Angew. Chem. Int. Ed. 2016, 55, 862-875. (e) Nandakumar, A., Midya, S. P., Landge, V. G. Balaraman, E. Angew. Chem. Int. Ed. 2015, 54, 11022-11034. (f) Yang, Q.; Wang, Q.; Yu, Z. Chem. Soc. Rev. 2015, 44, 2305-2329. (g) Obora, Y. ACS Catal. 2014, 4, 3972-3981. (h) Gunanathan, C.; Milstein, D. Science 2013, 341, 249. (i) Guillena, G.; Ramln, D. J.; Yus, M. Chem. Rev. 2010, 110, 1611-1641.

(4) Vispute, T. P., Zhang, H., Sanna, A., Xiao, R. Huber, G. W. Science 2010, 330, 1222-1227.

(5) Iron catalysis: (a) Yang, J.; Liu, X.; Meng, D.-L.; Chen, H.Y.; Zong, Z.-H.; Feng, T.-T.; Sun, K. Adv. Synth. Catal. 2012, 354, 328-334. (b) Elangovan, S.; Sortais, J.-B.; Beller, M.; Darcel, C. Angew. Chem. Int. Ed. 2015, 54, 14483-14486. Cobalt catalysis: (c) Freitag, F.; Irrgang, T.; Kempe, R. Chem. Eur. J. 2017, 23, 12110 12113. (d) Zhang, G.; Wu, J.; Zeng, H.; Zhang, S.; Yin, Z.; Zheng, S. Org. Lett. 2017, 19, 1080-1083. Manganese catalysis: (e) Pena-Lopez, M.; Piehl, P.; Elangovan, S.; Neumann, H.; Beller, M. Angew. Chem. Int. Ed. 2016, 55, 14967-14971. (f) Fu, S.; Shao, Z.; Wang, Y.; Liu, Q. J. Am. Chem. Soc. 2017, 139, 11941-11948. (g) El-Sepelgy, O.; Matador, E.; Brzozowska, A.; Rueping, M. ChemSusChem, 2018 doi,10.1002/cssc.201801660. (h) Liu, T.; Wang, L.; Wu, K.; Yu, Z. ACS Catal. 2018, 8, 7201-7207. (i) Kulkarni; N. V.; Brennessel; W. W.; Jones; W. D. ACS Catal. 2018, 8, 997-1002. (j) Barman, M. K.; Jana, A.; Maji, B., Adv. Synth. Catal. 2018, 360, 3233 - 3238.

(6) Methylation of ketones by base metals catalysis: (a) Liu, Z.; Yang, Z.; Yu, X.; Zhang, H.; Yu, B.; Zhao, Y.; Liu, Z. Org. Lett. 2017, 19, 5228-5231. (b) Polidano, K.; Allen, B. D. W.; Williams, J. M. J.; Morrill, L. C. ACS Catal. 2018, 8, 6440-6445. (c) Sklyaruk, J.; Borghs, J.C.; El-Sepelgy, O.; Rueping, M. Angew. Chem. Int. Ed. 2018, doi:10.1002/anie.201810885.

(7) (a) Guo, L.; Ma, X.; Fang, H.; Jia, X.; Huang, Z. Angew. Chem. Int. Ed. 2015, 54, 4023-4027. (b) Guo, L.; Liu, Y.; Yao, W.; Leng, X.; Huang, Z. Org. Lett. 2013, 15, 1144-1147. (c) Iuchi, Y.; Obora, Y.; Ishii, Y. J. Am. Chem. Soc. 2010, 132, 2536-2537.

(8) (a) Kuwahara, T.; Fukuyama, T.; Ryu, I. RSC Adv. 2013, 3, 13702-13704. (b) Moreshwar B. C.; Girish S. B.; Pooja K.; Boopathy G. Biomol. Chem., 2016, 14, 9215-9220. 10789.
(10) (a) Chirik, P.; Morris, R. Acc. Chem. Res. 2015, 48, 2495 2495. (b) Bauer, I.; Knölker, H.-J. Chem. Rev. 2015, 115, 3170-3387. (c) Morris, R. H. Acc. Chem. Res. 2015, 48, 1494-1502. (d) Bullock, R. M., Catalysis without Precious Metals. Wiley-VCH: Weinheim, 2010. (e) Plietker B., Iron Catalysis in Organic Chemistry: Reactions and applications, 2nd ed., Wiley-VCH, Weinheim, 2008.

(11) Selected examples: (a) Elangovan, S.; Topf, C.; Fischer, S.; Jiao, H.; Spannenberg, A.; Baumann, W.; Ludwig, R.; Junge, K.; Beller, M., J. Am. Chem. Soc. 2016, 138, 8809 - 8814. (b) Kallmeier, F.; Irrgang, T.; Dietel, T.; Kempe, R. Angew. Chem., Int. Ed. 2016, 55, 11806-11809. (c) Widegren, M. B.; Harkness, G. J.; Slawin, A. M. Z.; Cordes, D. B.; Clarke, M. L.; A. Angew. Chem. Int. Ed. 2017, 56, 5825 -5828. (d) Bruneau-Voisine, A.; Wang, D.; Dorcet, V.; Roisnel, T.; Darcel, C.; Sortais, J. B. Org. Lett. 2017, 19, 3656-3659. (e) Perez, M.; Elangovan, S.; Spannenberg, A.; Junge, K.; Beller, M., ChemSusChem 2017, 10, 83-86. (f) Zirakzadeh, A.; de Aguiar, S. R. M. M.; Stöger, B.; Widhalm, M.; Kirchner, K. ChemCatChem 2017, 9, 1744-1748. (g) Garbe, M.; Junge, K.; Walker, S.; Wei, Z.; Jiao, H.; Spannenberg, A.; Bachmann, S.; Scalone, M.; Beller, M. Angew. Chem. Int. Ed. 2017, 56, 11237-11241. (h) Wang, D.; BruneauVoisine, A.; Sortais, J.-B. Catal. Commun. 2017, 105, 31-36. (i) Bruneau-Voisine, A.; Wang, D.; Roisnel, T.; Darcel, C.; Sortais, J.-B., Catal. Commun. 2017, 92, 1-4. (j) Glatz, M.; Stöger, B.; Himmelbauer, D.; Veiros, L. F.; Kirchner, K. ACS Catal. 2018, 8, 4009-4016. (k) Zubar, V.; Lebedev, Y.; Azofra, L. M.; Cavallo, L.; El-Sepelgy, O.; Rueping, M. Angew. Chem. Int. Ed. 2018, 57, 13439 -13443. (1) Wei, D.; Bruneau-Voisine, A.; Chauvin, T.; Dorcet, V.; Roisnel, T.; Valyaev, D. A.; Lugan, N.; Sortais, J.-B. Adv. Synth. Catal. 2018, $360,676-681$.

(12) (a) Brzozowska, A.; Azofra, L. M.; Zubar, V.; Atodiresei, I; Cavallo, L.; Rueping, M.; El-Sepelgy, O. ACS Catal. 2018, 8, 4103-4109. (b) Zhou, Y. P.; Mo, Z.; Luecke, M. P.; Driess, M. Chem. Eur. J. 2018, 24, 4780- 4784.

(13) For Mn-catalyzed olefination with primary alcohols: (a) Chakraborty, S.; Das, U. K.; Ben-David, Y.; Milstein, D. J. Am. Chem. Soc. 2017, 139, 11710-11713. (b) Zhang, G.; Irrgang, T.; Dietel, T.; Kallmeier, F.; Kempe, R. Angew. Chem. Int. Ed. 2018, 57, 9131-9135. (c) Barman, M. K.; Waiba, S.; Maji, B. Angew. Chem. Int. $E d .2018$ 57, 9126-9130. For Mn-catalyzed $C$-alkylation of and nitriles with primary alcohols: (d) Jana, A.; Reddy, C. B.; Maji, B. ACS Catal. 2018, 8, 9226-9231.

(14) For Mn-catalyzed $\mathrm{N}$-alkylation with primary alcohols: (a) Elangovan, S.; Neumann, J.; Sortais, J.-B.; Junge, K.; Darcel, C.; Beller, M. Nat. Commun. 2016, 7, 12641. (b) Neumann, J.; Elangovan, S.; Spannenberg, A.; Junge, K.; Beller, M. Chem. - Eur. J. 2017, 23, 5410-5413. (c) Bruneau-Voisine, A.; Wang, D.; Dorcet, V.; Roisnel, T.; Darcel, C.; Sortais, J.-B. J. Catal. 2017, 347, 57-62. (c) Mastalir, M.; Pittenauer, E.; Allmaier, G.; Kirchner, K. J. Am. Chem. Soc. 2017, 139, 8812-8815. (d) Fertig, R.; Irrgang, T.; Freitag, F.; Zander, J.; Kempe, R. ACS Catal. 2018, 8, 8525-8530.

(15) For recent reviews on Mn-catalysis: (a) Gorgas, N.; Kirchner, K., Acc. Chem. Res. 2018, 51, 1558-1569. (b) Filonenko, G. A.; van Putten, R.; Hensen, E. J. M.; Pidko, E. A. Chem. Soc. Rev. 2018, 47, 1459-1483. (c) Zell, T.; Langer, R. ChemCatChem 2018, 10, 19301940. (d) Kallmeier, F.; Kempe R. Angew.Chem. Int. Ed. 2018, 57, 46-60. (e) Maji, B.; Barman, M. K. Synthesis 2017, 49, 3377-3393. (f) Garbe, M.; Junge, K.; Beller, M. Eur. J. Org. Chem. 2017, $4344-$ 4362. (g) Valyaev, D. A.; Lavigne, G.; Lugan, N., Coord. Chem. Rev. 2016, 308, 191-235. (h) Carney, J. R.; Dillon, B. R.; Thomas, S. P., Eur. J. Org. Chem. 2016, 3912-3929.

(16) For details, see supporting information.

(17) For reviews on metal-ligand catalysis, see: (a) Khusnutdinova, R.; Milstein, D. Angew. Chem. Int. Ed. 2015, 54, 12236-12273. (b) Luca, O. R.; Crabtree R. H. Chem. Soc. Rev. 2013, 42, 1440 - 1459. (c) Lyaskovskyy, V.; de Bruin, B. ACS Catal. 2012, $2,270-279$

(18) (a) Clapham, S. E.; Hadzovic, A.; Morris, R. H. Coord. Chem. Rev. 2004, 248, 2201-2237. (b) Samec, J. S. M.; Bäckvall, J.E.; Andersson, P. G.; Brandt, P. Chem. Soc. Rev. 2006, 35, 237-248.

(19) (a) El-Sepelgy, O.; Alandini, N.; Rueping, M. Angew. Chem. Int. Ed. 2016, 55, 13602-13605. (b) El-Sepelgy, O.; 
Brzozowska, A.; Rueping, M., ChemSusChem 2017, 10, 1664-1668. (c) El-Sepelgy, O.; Brzozowska, A.; Azofra, L. M.; Jang, Y. K.; Cavallo, L.; Rueping, M. Angew. Chem. Int. Ed. 2017, 56, 1486314867. (d) El-Sepelgy, O.; Brzozowska, A.; Sklyaruk, J.; Jang, Y. K.; Zubar, V.; Rueping, M.; Org. Lett. 2018, 20, 696-679.

(20) (a) Hasanayn, F.; Morris, R. H., Inorg. Chem., 2012, 51, 10808-10818. (b) Hasanayn, F.; Baroudi, A.; Bengali, A. A.; Goldman, A. S., Organometallics 2013, 32, 6969 - 6985. (c) Dub, P. A.; Henson, N. J.; Martin, R. L.; Gordon, J. C., J. Am. Chem. Soc. 2014,
136, 3505-3521. (d) Pan, H.-J.; Zhang, Y.; Shan, C.; Yu, Z.; Lan, Y.; Zhao, Y. Angew. Chem. Int. Ed. 2016, 55, 9615-9619.

(21) During the review of this manuscript, a related paper has been published with only NMR or GC yields: Chakraborty, S.; Daw; P.; Ben David, Y.; Milstein, D., ACS Catal. 2018, 8, 10300-10305. 


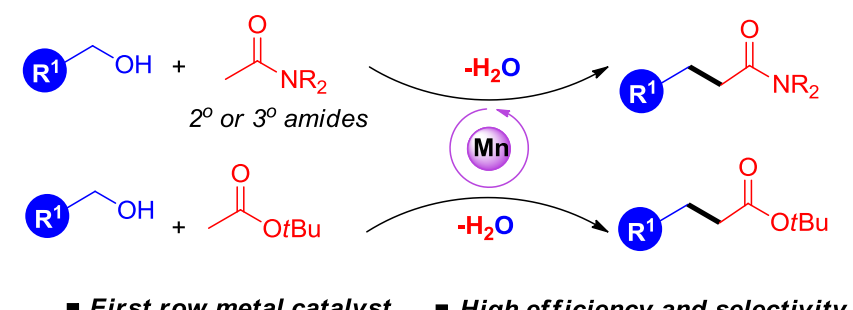

- First row metal catalyst - High efficiency and selectivity - Functionalization of unactivated feedstocks 